\title{
2 \\ Theory and constitutional framework of German federalism
}

\section{Introduction}

As in the case of the American states, the German Länder existed before the federation. But unlike the United States, there is no legal controversy in Germany over the role of the states as opposed to the "people" in creating the federation. ${ }^{1}$ Representatives from the Länder met at Herrenchiemsee in 1948 to draft the new constitution and formed the Parliamentary Council which negotiated with the Allies over the final text in 1949. The German Constitution, or Basic Law, was then approved by the parliaments of the Länder (except Bavaria) rather than by popular referendum. This does not make the Federal Republic the creature of the German Länder, however; the Preamble states specifically that the Basic Law is the result of an act by the German people.

In accordance with the tradition of civil law countries on the European continent, the Basic Law is long and detailed in comparison to the very brief US Constitution. ${ }^{2}$ The Basic Law has 146 articles, in comparison to seven original articles and twenty-seven amendments in the American Constitution. It has been amended fifty times since 1949 in comparison to seventeen times for the American Constitution since the first ten amendments were added in 1791. Some of the German amending laws have contained multiple changes of old articles or additions of new articles, so that the total number of changes is actually much larger than fifty. As these numbers suggest, it is easier to change the Basic Law by a two-thirds majority vote in the Bundestag (the popularly elected national parliament) and Bundesrat (a second legislative chamber in which the governments [cabinets] of the Länder are represented) than in the United States, which requires not only a two-thirds vote in the House and Senate but also majority approval by the legislatures in three-fourths of the 
states. It can be argued, of course, that the Supreme Court is an instrument of continuing constitutional change in the United States, since its decisions serve in some ways as a substitute for formal constitutional amendment. But this is true also, if perhaps to a lesser extent, of the Federal Constitutional Court in Germany.

About one-half of the articles of the Basic Law are related in a direct or indirect manner to federalism, and most amendments have concerned some aspect of the subject. In the first paragraph of Article 20, the Federal Republic is described as "a democratic and socially conscious [sozialer] federal state." Federalism, though not defined by the Basic Law, is even protected by a "perpetuity clause" (Article 79, para. 3) which forbids changes in "the division of the federation into Länder" or which affects their fundamental participation in the legislative process. The first clause does not protect individual Länder from boundary changes or consolidation as prescribed elsewhere in the Basic Law (Article 29); however, it does exclude any fundamental change from a federal to a unitary state. ${ }^{3}$ The second clause concerning participation in the legislative process means participation in the Bundesrat.

\section{Two or three tiers?}

Controversy over the nature of federalism in the United States has always focused on the federal government, i.e., the Union, the federation, federal level, federal tier, or federal plane vs the states. The Civil War decided the issue of the right of American states to secede, and the Supreme Court declared in 1868 that the United States was an indestructible union composed of indestructible states. ${ }^{4}$ The issue of contention has usually been disagreement over the location of sovereignty between two tiers of government or, at the very least, over the proper distribution of powers between them. ${ }^{5}$ When Ronald Reagan claimed in his inaugural presidential address in 1981 that the states created the Union, thus implying state sovereignty, few legal scholars agreed. But just where sovereignty does lie is still an unresolved question. Daniel Elazar, for example, insists that in a democratic federal system sovereignty is shared; each arena or "plane" (he rejects the term "level") of government derives its sovereignty from "the people," and no one arena is superior to the other. ${ }^{6}$ Paul Peterson, on the other hand, speaks of "levels" and argues that since the Civil War sovereignty has been "concentrated in the hands of the national government." 7 
While German scholars since 1949 have not argued about the location of sovereignty, there have been some differences among them over the conception of the German federal state as having two or three tiers or levels. Those who see a two-tier or two-systems model "see the Länder as subsystems of the federation." The Bund is the federation and is endowed with the powers of a federal government. Advocates of the three-tier or three-systems model "distinguish among the Länder, the central state, and the federation." The Bund is the central state with the powers of a federal government, while the "federation is seen as a rather powerless system embracing both the Länder and the central state. The central state is a mere subsystem of the federation, as are the Länder." Bund and Länder are almost equal partners, "both subject to the all-embracing though somewhat nebulous federation." ${ }^{8}$ In this case the federal president and the Federal Constitutional Court would be organs of the federation, while the federal government (Bundesregierung) and the Bundestag would be organs of the central state and the federation. In the two-tier model, on the other hand, all federal organs are organs of the federation. ${ }^{9}$

An early decision of the Federal Constitutional Court seemed to suggest that the Court accepted the three-tier model, but later it made clear its preference for two tiers. Some scholars believe that "a resurrection of the "three systems model" cannot be excluded," 10 while others argue vehemently that "the Federal Republic is no three-tier federation." 11 The two-tier model seems to be the consensus among scholars today. ${ }^{12}$

\section{The division of legislative, executive, and judicial powers}

As we shall see below, a general principle guides the division of powers or functions in the Basic Law. That principle is contained in Article 30, which says that "state [Americans would say "governmental"] powers and the implementation of state [governmental] tasks are the responsibility of the Länder," unless the Basic Law provides otherwise. This creates a presumption that governmental powers - legislative, executive, and judicial - lie with the Länder in cases of doubt. ${ }^{13}$ But as with the Tenth Amendment ${ }^{14}$ to the American Constitution, the provisions of Article 30 are somewhat misleading. ${ }^{15}$ Indeed, Fritz Scharpf has suggested that such provisions are a "living lie [Lebenslüge] of federalism." ${ }^{16}$ 


\section{Division of legislative powers between the federal and Land governments ${ }^{17}$}

The general provisions of Article 70

An entire section (Section VII) of fifteen articles in the Basic Law deals with legislation. The first of these, Article 70, is closely related to Article 30 above. It states simply that "the Länder have the right of passing legislation insofar as this Basic Law does not grant legislative authority to the federation." This means that in contrast to the United States there is little room or necessity for implied powers. There is a somewhat similar doctrine in German law of granting powers based on the "nature of the material" (aus der Natur der Sache) and "subject interrelationship" (Sachzusammenhang), but these are used only rarely and under certain conditions and are not considered really comparable to American implied powers. ${ }^{18}$

Article 70, para. 2, says that legislative authority is granted in the form of exclusive and concurrent legislative powers. A third important source of legislative authority for the federation, not mentioned in Article 70, is found in framework legislation, which is taken up in Article 75. As indicated above, one can also add unwritten powers based on "the nature of the material" or "subject interrelationship," but these are highly restricted by the requirement of Article 70 that powers of the federation are derived from provisions of the Basic Law. Finally, one should add European law as an increasingly important source of law in Germany which affects both federal and Land lawmaking powers.

The constitutional reality today is that there are relatively few legislative powers that have not been granted to the federal level by various means. ${ }^{19}$ Areas generally left to the Länder are local governments; culture, including schools as well as the visual or performing arts and electronic media; public safety, e.g., police; and some aspects of civil service and health care. ${ }^{20}$

\section{Exclusive federal powers}

In spite of the provisions of Articles 30 and 70, the legislative powers of the federation are much greater than those of the Länder. This is made clear in Articles 71-75. Article 71 denies the Länder any powers in the areas of exclusive federal jurisdiction unless they have been granted specifically by federal law. Thus a law passed by a Land legislature or a popular referendum in a Land or unit of local government that demanded some action or inaction by the federal government in an area of its exclusive jurisdiction, e.g., national defense, would be unconstitutional. ${ }^{21}$ 
The exclusive legislative powers of the federation are listed in Article 73. There are twelve "paragraphs,"most of which contain rather obvious responsibilities for the federal government, for example, foreign affairs and defense; national citizenship; currency, weights and measures; customs and foreign trade; air and rail transport owned by the federation; postal and telecommunications services; and several other matters. The list is not complete, because many other federal responsibilities can be found in other provisions of the Basic Law.22 The power to regulate asylum seekers, for example, is found in Article 16, while the regulation of political parties and political finance is authorized in Article 21. There are also certain executive powers, such as planning, that are found in other articles. ${ }^{23}$ There is no comparable catalogue of powers for the Länder, because they retain under Articles 30 and 70 all legislative powers not granted to the federation. In the case of foreign affairs, Article 73, para. 1, does not mention specifically foreign aid, which has led the Länder to establish their own separate foreign aid programs while recognizing the primacy of the federation in this area (Article 32$).^{24}$

\section{Concurrent powers}

Articles 72 and 74 are concerned with concurrent powers. Both articles became subjects of discussion as a result of Article 5 of the Unification Treaty of 1990 which "recommends"that the Bundestag and Bundesrat consider constitutional changes "with respect to the relationship between the federation and the Länder . .."25 In 1992 these two legislative bodies formed a Joint Constitutional Commission which recommended a number of modest changes to the Basic Law, including some changes to Articles 72, 74, and 75 which deal with the distribution of legislative powers between the federation and the Länder. ${ }^{26}$ The changes recommended by the Joint Constitutional Commission were generally accepted by the Bundestag and Bundesrat, but some revisions were made. ${ }^{27}$ The final result of these efforts was a $42 \mathrm{nd}$ amendment law that changed eleven Articles of the Basic Law and added three new ones. $^{28}$

The revised Article 72 contains three paragraphs. The first of these states simply that the Länder have the power to act in the area of concurrent legislation so long and so far as the federation has not "used" its power to pass legislation in the area of concern ("has used" was inserted in 1994 to mean having gone through the entire legislative process ${ }^{29}$ ). According to the Basic Law, any action the federal government takes in the area of concurrent legislation preempts any Land legislation covering 
the same subject, not just provisions that may be in conflict, as in the United States. ${ }^{30}$ That is, there is no "dual authority." 31 Therefore, some legal scholars suggest that "precedence" legislation might be a better term than "concurrent" legislation. ${ }^{32}$

The changes made to Article 72 in the 1994 amendments are rather subtle and esoteric but nevertheless important. In para. 2 the federation can now claim a concurrent power for itself only if it is "essential" or "required" (erforderlich) and not just because it perceives a "need" (Bedürfnis) to act. In the past the federation could claim a "need" to act because a matter could not be regulated effectively by individual Länder, because regulation by a Land could affect the interests of other Länder or the whole (in both cases rare occurrences ${ }^{33}$ ), or because the legal and economic unity of the country required the "uniformity [Einheitlichkeit] of living conditions." These were, of course, such general provisions that they allowed the federation very broad authority. As of October 1994, however, the federal government can claim a federal preemption to be "essential" only in the general interest of preserving "equivalent [ gleichwertige] living conditions" or the legal and economic unity of the country. The standard of equivalency is less strict than uniformity, about which there was considerable misunderstanding in Germany among politicians and even some jurists.

Some legal experts insisted that "uniform living conditions" never did mean equality in any literal or leveling sense; rather, it meant providing equal opportunities in education; necessary infrastructure for a modern economy, including transportation; certain environmental standards, including green spaces and recreation facilities, etc., ${ }^{34}$ in addition to an adequate standard of living to be achieved, if necessary, through the welfare state. Whatever the original intent might have been, some scholars have concluded that the uniformity clause was an "empty formula" that could be filled to suit a variety of purposes. ${ }^{35}$

There can be little doubt that demands to eliminate differences in living standards - emerging not only from constitutional interpretation but also from the public - have had a strong "unitary" or centralizing effect on the federal system in Germany. ${ }^{36}$ This is why there was pressure even before German unification, but especially afterwards, to make Article 72 less sweeping in its language. Thus, it was thought that it is more feasible for the Länder to provide for "equivalency" in their territory than to achieve "uniformity" of living conditions, because equivalency can vary from Land to Land. Furthermore, under a new provision added to Article 93 by the changes introduced in 1994, the Land governments, Land 
parliaments, and the Bundesrat can take any disagreements over what is "essential" to the Federal Constitutional Court, which they could not do before the 1994 changes. ${ }^{37}$

Finally, a third paragraph for Article 72 was introduced in 1994 in order to return power to the Länder ${ }^{38}$ if and when a "requirement" for federal action no longer exists. ${ }^{39}$ Whether this and the changes noted above will in fact have much of an impact on the legislative power relations between the federation and the Länder remains to be seen. The federation already has virtually exhausted its possibilities in the area of concurrent powers, and it seems doubtful that it will agree to transfer many - or any - of the subjects it now regulates back to the Länder.

Article 74 provides a list of the concurrent powers that in theory at least could have remained with or been assumed by the Länder. The list now contains twenty-eight subject areas, including numerous areas that have always been and remain responsibilities of the American states, such as civil and criminal law. The American concept of concurrent legislation also permits the states to pass or retain legislation in areas in which the federal government has acted except in cases where specific provisions are in conflict. In general the German federation has assumed most of the powers in the general areas of economics, employment conditions, welfare, and justice affairs. As we saw above, the Länder have retained responsibility for other areas, especially "culture," which includes schools as well as the arts and electronic media; local government; police; and a few other matters.

While these are important functions, they pale in significance to the concurrent legislative powers of the federation. These are even more extensive than Articles 72 and 74 suggest. For example, in order to eliminate financially damaging competition among themselves, the Länder agreed via the Bundesrat to grant to the federation in Article 74a the concurrent power of regulating the salary and benefits of the civil service (Beamte), including the Land civil service, insofar as this power is not already included in the federation' s exclusive powers. This was a rather significant voluntary abdication of the right of the Länder to regulate their own personnel..$^{40}$ The tax provisions of Article 105, para. 2, are another example of concurrent power that will be discussed in a later chapter. ${ }^{41}$ Finally, in case of war Article $115 \mathrm{c}$ gives the federal government certain concurrent powers normally in the hands of the Länder. ${ }^{42}$ In each of the above cases, however, the federal government needs the approval of a majority of the Bundesrat. 


\section{Framework legislation}

In addition to exclusive and concurrent powers, framework legislation as provided by Article 75 of the Basic Law is an important source of power for the federation. Framework laws are different from the laws passed under the federation's exclusive and concurrent powers, however, in that they are directed at the Land legislators for further legislative action by them. It is assumed that the legislative details to be completed by the Land legislators are of some significance and are arrived at freely; indeed, in order in part to prevent the repetition of some past federal intrusiveness, a new paragraph inserted in Article 75 in 1994 states specifically that framework legislation may go into detail only in exceptional cases. ${ }^{43}$ Some restrictions have been placed on the federation by the changes of 1994 in that the provisions of Article 72 apply, according to which the federation must now demonstrate not merely a "need" but rather a "requirement" for framework legislation. An additional item, the protection of cultural artifacts against foreign acquisition, was added in 1994 to the list of six general subjects that can be regulated by framework legislation, while film (movies) was removed and given to the Länder. One subject, the regulation of public service personnel, must be seen in conjunction with Article $74 \mathrm{a}$, discussed above, which regulates the salary and benefits of civil servants (Beamte) as a special category of public service personnel. The general regulation of universities in framework legislation must also be viewed together with Article 91a and 91b, which established a number of "joint tasks" (Gemeinschaftsaufgaben) in the constitutional reforms (Finance Reform) of 1969.

\section{Administration in the German federal system}

Article 83 and "dual federalism"

Just as one section of the Basic Law deals with the distribution of legislative powers between the federation and the Länder, another (Section VIII) deals with the implementation of federal legislation. The first article (Article 83) of this section states simply that "[t]he Länder implement federal legislation on their own responsibility so long as this Basic Law does not provide otherwise." The language of this Article shows its relationship to Articles 30 and 70 above in granting sweeping authority to the Länder unless the Basic Law provides otherwise.

Article 83 is a reflection of the concept of "dual federalism" in Germany. As we have seen above, the federation in fact carries most of the responsibility for legislation, while the Länder are primarily responsible 
for administration. For this reason, German federalism is sometimes referred to as "administrative federalism." The division of responsibilities in German federalism is not one of strict separation, however; rather, it is a system of cooperation, interconnections, and interrelationships. The federation carries the greatest responsibility for legislation, but the Länder participate in legislation via the Bundesrat. The Länder are generally responsible for administration, but in carrying out federal laws they may be subject to many federal instructions and restrictions which they can usually influence via the Bundesrat. ${ }^{44}$ The exception to the general rule is found at the local level, where certain core functions are protected by Article 28, para. 2, from any direction from above. ${ }^{45}$

This is very different from the American concept of "dual federalism" or "dual sovereignty," according to which a duality exists between the federal government and its executive and legislative powers on the one hand and the states and their executive and legislative powers on the other hand. ${ }^{46}$ While these two concepts of dual federalism are not as distinguishable in practice as one might assume, they do represent a clear difference in the German and American federal traditions. They also contribute to some confusion in the sense that some German scholars speak of a "functional" division between federal legislative and Land administrative responsibilities, while American scholars (as well as some Germans $^{47}$ ) usually focus on the distinction between public "tasks" or "functions" performed by federal authorities and those performed by state or local governments when referring to "functional" divisions.

We saw above that once the federation has acted in the area of concurrent legislative power, any legislation already passed by the Länder on the same subject is preempted by the federal law, i.e., there is no dual legislative responsibility in Germany except in the limited cases that fall under framework laws and "joint tasks." In principle either one level or the other has legislative responsibility, not both. The same principle applies in administration; however, here there are numerous exceptions to the rule. ${ }^{48}$ Indeed, the many exceptions, whether by design or by practice, have contributed to the concept of "cooperative federalism" which is now commonly used in describing German federalism. It is a concept borrowed from the United States, where "cooperative federalism" was used to describe the reality of shared financing and administrative responsibilities that emerged during and after the New Deal in contrast to the theory of "dual federalism" that prevailed before the 1930s. ${ }^{49}$ As noted above, the Finance Reform of 1969 in Germany led to a number of constitutional changes that included the introduction of two new articles providing for 
the carrying out of "joint tasks" (Gemeinschaftsaufgaben) by the federation and the Länder: Article 91a and 91b.

\section{The administration of Federal and Land laws}

The German "state" at the federal level is a lawmaking state, while at the Land level it is an administrative state. The federation is more dominant in legislation than the Länder are in administration, but administration is still the key element of Land autonomy. ${ }^{50}$ Article 83 of the Basic Law, translated above, makes this clear. However, as in the cases of Article 30 and Article 70, which reserve legislative powers to the Länder unless the Basic Law provides otherwise, there are many opportunities for federal involvement in administration based on provisions of the Basic Law. Indeed, Section VIII provides three methods of administering federal law.

Bundeseigene Verwaltung An obvious, but not common, method is administration solely by federal officials (Bundeseigene Verwaltung) as either required or authorized by the Basic Law. ${ }^{51}$ This takes place directly in state agencies, e.g., finance administration, or indirectly, e.g., social insurance agencies, where unity throughout the Federal Republic is required. The Basic Law lists the areas that fall under exclusive federal administration in Articles 87, 87a and 87b, 87d-87f, and 88-89. Article 87 , para. 1 , provides for federal administration of the foreign service, federal finances, federal waterways and shipping; it also authorizes the federal government to establish administrative agencies for border patrol, certain federal police services, and constitutional protection. Paragraph 2 calls for direct federal administration in cases of social insurance programs when the territory covered goes beyond a single Land. The other articles mentioned above deal with federal administration of military forces; air transportation; railroads, post office and telecommunications (railroads, many post office functions and telecommunications were privatized in whole or in part in the mid-1990s); the Bundesbank (federal reserve bank); and federal waterways. ${ }^{52}$

Bundesauftragsverwaltung A second method is administration by the Länder of federal laws delegated to them (Bundesauftragsverwaltung), that is, administration by the Länder according to federal instructions (Article 85$).{ }^{53}$ It represents a "middle way" between administration by federal agencies and by Land agencies on their own responsibility; however, it is still Land administration. ${ }^{54}$ The federal government pays the functional costs, but the Länder pay the administrative costs. Federally 
delegated administration occurs only if provided by the Basic Law or because of a constitutionally authorized federal law. ${ }^{55}$ Land administration of the federal autobahns and other federal long-distance highways and the administration of major taxes are provided directly by Article 90 and Article 108, para. 1, respectively. Other subjects, such as nuclear energy and some aspects of air transportation, can be given to the Länder with the approval of the Bundesrat (Article 87c and 87d), and, upon application, federal waterways can be administered by a Land.

The delegation of federal laws to the Länder for administration increased with the passage of the Finance Reform package of 1969. Article $104 \mathrm{a}$, for example, provides that when the federation pays 50 percent or more of the costs of a program, that program is to be delegated to the Länder for administration. An example is educational assistance legislation (Bundesausbildungsförderungsgesetz), under which about one-third of higher-level pupils (Schüler) and more than 40 percent of university students receive varying degrees of financial aid for expenses other than tuition, which is free (by the end of the 1990s, there was growing pressure to introduce modest tuition charges). The complex relationships between federal and Land agencies involved in the administration of this legislation is eased to some extent by vertical contacts between the administrators involved and the effort by the federal authorities to coordinate the federal directives with the Land authorities. But such examples of delegated administration remain somewhat problematic, because the federal ministries end up heavily involved in administration..$^{56}$

Under Article 85 the federation provides for uniform rules of training for higher and middle-level civil servants who will be involved in implementing federal laws; blue-collar public employees (Arbeiter) are not included in this training. In rare cases the federal government also approves the heads of specialized "middle agencies" that execute delegated federal law, e.g., the head of the high finance offices. These provisions and the right of the federal ministries to issue instructions to the Land ministries under which the federal laws are administered demonstrate the extent of federal influence in Land administrative agencies. This influence was curtailed somewhat in 1999, when the Federal Constitutional Court ruled that the federal cabinet, with the approval of the Bundesrat, could issue administrative regulations for the implementation of federal laws. ${ }^{57}$ Before this decision federal ministers alone sometimes issued instructions to the Land authorities. On the other hand, federal guidelines and recommendations usually emerge as a result of committee and commission meetings composed of federal and Land officials. ${ }^{58}$ Thus federal instructions do not mean 
a federal takeover of Land administration; rather, the Land agencies are required to follow the "federal will." ${ }^{9}$ It should also be noted that federal agencies must not ignore federal comity, which in this case means providing the Land agencies with opportunities to respond and react to the federal instructions before taking the extreme actions authorized in Article 85 of demanding documents and sending officials to the Land agencies to ensure compliance with the "federal will." 60

Landeseigene Verwaltung A third type of administration, which is the most common of all, is that carried out by the Länder themselves. That is, the Länder and local governments, to which the Länder send as many as 75 percent of "state" (federal and Land) laws for execution, ${ }^{61}$ have the right to administer higher-level laws on their own responsibility. According to Article 84, if the Länder execute federal legislation, they establish the agencies and regulatory procedures under their organizational powers as matters of their own responsibility (als landeseigene Angelegenheit), which is generally referred to as autonomous Land administration (Landeseigenverwaltung) ${ }^{62}$ however, a federal law, to which the Bundesrat has consented, may provide for federal involvement in the establishment of agencies or in administrative procedures. Where the Länder administer federal laws on their own responsibility, they pay both the administrative and functional costs; however, in cases where the Länder pay more than 25 percent of the functional costs, consent of the Bundesrat is required. (According to Article 104a, as noted above, if the federation pays for more than 50 percent of the costs, the law must be delegated to the Länder for administration by federal instructions.) Since there is nothing in Article 84 to suggest that the federation has to demonstrate a "need" to intervene but rather can do so to ensure an effective administration, there is a broad opportunity for federal involvement. ${ }^{63}$ Nevertheless, federal involvement occurs only with the approval of the Bundesrat, which means that in the final analysis the Länder - actually, the Land governments, i.e., cabinets - control the extent to which the federation becomes involved in Land administration.

Examples of this category of administration include federal traffic laws, federal emission control laws, waste disposal laws, and federal construction law. Federal laws administered by the Länder on their own responsibility can be based on exclusive or concurrent federal powers, and, to some extent, framework powers. Increasingly, the Länder are also implementing EU legislation on their own administrative responsibility ${ }^{64}$

In implementing federal laws, the Länder are supervised by federal authorities to ensure compliance and uniformity; however, whereas 
supervision in the case of delegated laws is both legal and functional, in the case of implementing federal laws on their own responsibility the Länder are under legal supervision only. If there is a conflict and no satisfactory resolution occurs, either side may take the case to the Bundesrat for a decision. If dissatisfied with this decision, either side can appeal to the Federal Constitutional Court. ${ }^{65}$

Since there are so many federal laws administered by the Länder, the consent of the Bundesrat is now required for more than half of the legislation passed by the Bundestag. It was originally thought by the founding fathers in 1949 that about 10 percent of federal laws would be consent laws. ${ }^{66}$ In part the increased role of the Bundesrat is due also to the interpretation by the Federal Constitutional Court that any federal law that contains a single provision concerning how the statute is to be administered by the Länder requires, as a whole, the consent of the Bundesrat. ${ }^{67}$ This makes it more difficult, but not impossible, for the government and Bundestag to separate one legislative bill's section from the others in order to avoid opposition and even a veto by the Bundesrat.

Administration of Land laws The Basic Law is silent concerning the fourth type of Land administration, i.e., the right of the Länder to administer their own laws and organize their own administrative structures. Land authority for these functions is presumed by Article 30. Thus Land constitutions and legislatures are decisive in the area of "own-law" administration. ${ }^{68}$

\section{Federal-Land cooperation}

As a general rule, German law does not permit a combination or mixture of federal and Land administration in a hierarchical relationship ${ }^{69}$ (Mischverwaltung) any more than it accepts dual legislative powers over the same subject. As indicated above, however, there are certain exceptions that are commonly referred to as "administrative cooperation" or, since the late 1970s, as "political-administrative interconnections"(Politikverflechtung $g^{70}$ ), a term similar to, but not quite the same as, "intergovernmental relations" in the United States. ${ }^{71}$ Cooperation between the federation and the Länder is sometimes referred to also as vertikale Verwaltungsverflechtung (vertical administrative interconnection). ${ }^{72}$ This occurs formally, of course, when the Länder participate in federal policy making via the Bundesrat, and, one might add, when they participate in EU policy making via the Bundesrat and their missions in Brussels.

A well-known form of cooperation which is even cited as an example of Mischverwaltung takes place under the category of "joint tasks" 
(Gemeinschaftsaufgaben) that are specified in the Basic Law in Article 91a and 91b. Article 91a, discussed briefly above, gives the federation the right of codecision (mitwirken) with the Länder in university building construction, in improving regional economic structures, and in improving conditions in agricultural and coastal areas. This requires joint planning between the federal and Land governments, described in the chapter on Land administration.

The "joint tasks" have been the subject of considerable discussion among German jurists, administrators, and politicians. ${ }^{73}$ Some point out that Article 91a and 91b recognized or even made constitutional a number of contractual agreements between the federation and the Länder that already existed before the Finance Reform of $1969 .^{74}$ The lack of a clear constitutional authorization for these cooperative agreements led to the creation of the Troeger Commission which issued a report in $1966^{75}$ that served as the basis for the Finance Reform of 1969 and the addition of Articles 91a, 91b, and 104a to the Basic Law. ${ }^{76}$ (Article 104a provides the federation with the authority to make financial grants to the Länder and is sometimes discussed along with Article 91a and 91b as an "ungenuine" joint task. ${ }^{77}$ ) In spite of this background, these new provisions soon became very controversial and a subject of investigation in a federal commission on constitutional reform (Enquete-Kommission Verfassungsreform) in 1976; however, no serious efforts were made to revise the joint task provisions.

The joint tasks are defended not only on historical grounds but also on the grounds that otherwise the federal government would have no constitutional authorization to act in important areas. However, federal authorities cannot require action. The federal government participates only in framework planning; every Land government has the right to reject its application in its territory. The federal government does not become involved in detailed planning, and each Land implements the framework as it wishes. The projects are financed jointly. ${ }^{78}$

The basic criticism of these provisions, however, is that they have added significantly to the legislative and administrative powers of the federation at the cost of the Länder. These may have been compensated to some extent through their participation via the Bundesrat, but joint administration and joint financing in particular have been responsible for a general trend toward a reduction in the importance of the Länder. ${ }^{79}$ The federation has used extensively the instruments of cooperation granted it in Article 91a and 91b, with the result that the Länder see a continued narrowing of their freedom of decision making and of their 
financial room for maneuver. ${ }^{80}$ The agreements among bureaucrats in participating ministries at the federal and Land levels serve to narrow the room left for decision making by those drawing up budgets at both levels and for the Land parliaments that can do little to change the executive decisions already reached. ${ }^{81}$

A form of cooperation takes place also when the federal government provides the Länder with grants-in-aid under Article 104a, para. 4. As in the United States, complaints are sometimes heard that these grants interfere with Land or local autonomy, but empirical evidence does not support these claims. In any case, as with the joint tasks, the federation is responding more to the needs expressed by the Länder than to any goals of its own. ${ }^{82}$

The weakest form of federal participation in Land administration is federal supervision and control. If the Land is administering a federal law delegated to it, the responsible federal minister has the power of subject matter and legal supervision; he or she exercises legal supervision only if the law is being administered as a matter of Land responsibility. In practice supervision usually consists of an exchange of information and consultation..$^{83}$

\section{Cooperation among the Länder}

There are numerous examples of cooperation between the Länder and the federal government and among the Länder themselves. Indeed, the Land parliament of North-Rhine Westphalia conducted a study in 1989 according to which there were 330 federal-Land commissions and 120-140 commissions involving North-Rhine Westphalia and other Länder without federal participation. ${ }^{84}$ These are examples of vertical and horizontal coordination, respectively. The purpose of such coordination efforts is to resolve practical problems, usually requiring cross-boundary cooperation, that can be either temporary or permanent in nature. ${ }^{85}$

Horizontal cooperation between and among the Länder is said to take place at a kind of extra-constitutional "third level" between the federation and the Länder. The conferences of Land prime ministers take place about every three months to consider common demands on the federation, and subject ministers in the Länder meet regularly to consider a wide variety of themes, including draft legislation. ${ }^{86}$

The most common and best-known legal instrument of cooperation among the Länder is the interstate compact. It is based neither on federal law nor on Land law but rather on "cooperative customary law" (Kooperationsgewohnheitsrecht) that exists between the federation and the Länder 
at the "third level." 87 There are two forms of compact: the "administrative agreement" and the "state contract." The difference is that the first form is restricted to the executive authorities of the Länder, e.g., the administrative agreement in 1952 among the Länder and, in this case, the federation, regarding the German Postgraduate School of Administrative Sciences (Deutsche Hochschule für Verwaltungswissenschaften) in Speyer ${ }^{88}$ whereas the second form, the "state contract," binds the Länder as such and must be approved by the Land parliaments, e.g., compacts establishing certain public radio and television networks and their listening and viewing fees or the compact regulating the distribution of students among the various universities. ${ }^{89}$ Compacts may involve all or only some of the Länder; for example, common planning institutions have been established for Hamburg and Lower Saxony and for Hamburg and Schleswig-Holstein, although the success of these institutions has been limited..$^{90}$

In addition to formal, legally binding compacts, there is the "political understanding" (politische Absprache), which is usually the result of a recommendation of a conference of Land ministers, whose goal, for example, might be to reach agreement on model legislation. These "understandings" are not legally binding, but they are considered to be politically and morally binding. ${ }^{91}$

The interstate compacts described here do not include certain wellknown activities such as the conference of Land prime ministers (Ministerpräsidentenkonferenz), the conferences of Land subject ministers, or the permanent conference of ministers of education and culture (Kultusminsterkonferenz (KMK)) or their various committees. These are executive cooperative bodies that do not possess any autonomous administrative authority.$^{92}$ They are, however, important elements in the federal political process. The conference of Land prime ministers, for example, serves a variety of functions, including guarantor of continuity for Land government actions in spite of changing majorities in the Bundesrat; control instrument vis-à-vis the federation and watchdog over EU developments; clearing house for various compacts among the Länder; and umpire for Land ministerial meetings. The rule of unanimity and rotating leadership of the prime ministers' conferences discourage a strong partisan approach. ${ }^{93}$

\section{A “unitary federal state" through interlocking, intergovernmental relations?}

Taking examples from both federal-Land cooperation, e.g., joint tasks, and cooperation among the Länder, critics point, among other things, to 
the inequality in the arrangements between the federation on the one hand and the Länder on the other; to the invasion of Land autonomy that results; and to the strengthening of Land executive powers at the cost of the Land parliaments. ${ }^{94}$ This is symbolized in part by the "traveling federalism" of high-level federal and Land ministerial bureaucrats who establish a "coordination bureaucracy" sometimes referred to as "vertical brotherhoods of experts" (Fachbrüderschaften). ${ }^{95}$ Some scholars argue that while cooperation is necessary and desirable, given the demands of a modern society and welfare state, practice in the Federal Republic may have exceeded the limits required for maintaining the autonomy of the Länder within the federal system. ${ }^{96}$

The numerous cases of federal-Land administrative cooperation and the "self-coordination" among the Länder, together with federal dominance in the legislative arena and the resulting federal supervision of the Länder in the administration of numerous federal laws, have led many scholars to speak of a "unitary federalism" in Germany. ${ }^{97}$ "Unitary federalism" does not quite conform to Daniel Elazar's description of a "decentralized" unitary state, because the former is the result more of voluntary cooperation and coordination by the federal units than of central direction. ${ }^{98}$

With the 1969 Finance Reform, "unitary" federalism was complemented and to some extent replaced by the term "cooperative federalism." This term was borrowed from the United States and was introduced to describe the growing practices of intergovernmental relations. As noted in several places above, Article 91a and $91 \mathrm{~b}$ are examples frequently cited, as are the joint taxes and selected legislation. A later, somewhat narrower, concept that reflects the centralizing trends described above and the complex interrelationships among various levels and institutions of government is "political-administrative interconnections" (Politikverflechtung), ${ }^{99}$ a term mentioned above that is similar to but not exactly the same as the American term "intergovernmental relations." 100 Politikverflechtung has become identified with numerous criticisms of German federalism, e.g., that the responsibility for policy making for and financing of various projects involving the federal and Land levels is unclear; that the budgets of the Länder both in respect to the initial project funding and follow-up costs are too restricted; that the sectoral planning between the federal and Land levels takes place at the cost of coordinated general planning at federal and Land levels, respectively; that the freedom of decision making in the parliaments at the federal and Land levels is narrowed; that the federal balance is endangered, the Länder weakened, the federation given too much planning power, and a systematic fiscal equalization in the federal system made 
more difficult; and that Politikverflechtung is characterized by a bureaucratized and expensive administrative procedure. ${ }^{101}$

Gerhard Lehmbruch, while acknowledging the contributions of Fritz Scharpf and his colleagues, suggests that "policy networks" would be a more descriptive term than Politikverflechtung. He sees this term as focusing too narrowly on interbureaucratic relations linking autonomous administrations and neglecting their links with societal actors, especially the political parties. ${ }^{102}$

Fritz Scharpf is known not only as the originator of the term Politikverflechtung, he is also widely cited for his thesis that the German federal system - and, for that matter, the EU - is characterized in much of its decision making by a "joint-decision trap." This "trap" is found especially in the decision-making process regarding the "joint tasks" but also in other areas, such as the Bundesrat, and it refers to the necessity of reaching compromises on all important issues since none of the parties in the decision-making group can dominate the others and unanimity is required for action. ${ }^{103}$ This thesis has become a very influential and widely cited explanation for the - for many Germans frustrating - "gridlock" or difficulty in achieving reforms in a variety of important political areas. Of the many current examples, one could name fiscal equalization (Chapter 5) and the related issue of territorial boundary reform of the Länder, health insurance, and tax policy (especially under Chancellor Kohl).

\section{Organization of the judiciary ${ }^{104}$}

The division of judicial powers, court organization, and certain procedures are found in Section IX of the Basic Law. As we saw above, Article 30 establishes the presumption that "state functions" are the responsibility of the Länder, and Article 92, though less clearly than Articles 70 and 83, presumes that judicial authority rests with the Länder.

Nevertheless, the Federal Constitutional Court is mentioned even in the first article of Section IX, i.e., Article 92. It is a constitutional organ to which Land courts must turn for interpretations of the Basic Law, therefore making unnecessary a case like Marbury v. Madison ${ }^{105}$ which established the right of judicial review in the United States. A ruling of a Land constitutional court can also be challenged via an individual "constitutional complaint" brought before the Federal Constitutional Court. Of course decisions of this court are binding on the Land constitutional courts. Thus there is some hierarchy in the relationship between the 
federal and Land constitutional courts, but not in a formal, structural sense. As in the United States, the constitutional courts of the two levels are basically separate in their fields of operation. An interesting difference to the United States, however, is that a Land, for example, SchleswigHolstein, may decide to turn over to the Federal Constitutional Court all constitutional questions rather than to establish a separate Land constitutional court of its own.

\section{The federal court system}

The Basic Law (Article 95) requires the establishment of five federal courts. These are the Federal Court of Justice in Karlsruhe (not to be confused with the Federal Constitutional Court in Karlsruhe), which is the highest appeals court for civil and criminal law; the Federal Administrative Court in Berlin (moved to Leipzig after 2002); the Federal Finance Court in Munich; the Federal Labor Court in Kassel (which will be transferred to Erfurt); and the Federal Social Court in Kassel. Unlike the Federal Constitutional Court, these are not constitutional organs. Their authority is not set by the Basic Law but by federal statutory law. These courts are the highest authorities within their subject area. The boundaries between them and their respective Land courts are set by federal law, and uniformity in their decisions is maintained by a "common senate" in Karlsruhe. Judges for these courts are selected by the federal ministers responsible for the subject area together with their counterpart ministers in the Länder and an equal number of Bundestag members.

Other federal courts may also be established by federal law. These are courts of first instance that answer to the Federal Court of Justice in Karlsruhe. Since the Basic Law went into effect in 1949, federal law has established a Federal Patents Court, disciplinary courts for public servants, military courts, and a disciplinary court for judges. With the consent of the Bundesrat, Land courts can rule on federal law in certain criminal cases involving agitation against other peoples or for aggressive war.

\section{Land courts}

All of the Länder except Schleswig-Holstein have established Land constitutional courts. These are autonomous courts whose organization, authority, and procedure are set by Land constitutions and laws. In contrast to the other courts, the Länder determine the salaries and compensation of their own constitutional court judges.

In accordance with Article 92, the bulk of judicial activity in Germany 
is at the Land level. The courts are organized at the lower and middle instances, i.e., at local and regional levels, and they follow the specialization of the federal courts as outlined above. Thus in normal civil and criminal cases, the levels are local (Amtsgericht), regional (Landgericht), and Land (Oberlandesgericht); for cases involving administrative law, there are the administrative courts and higher administrative courts; for labor cases, the labor courts and the Land labor court; and for social welfare cases, the social courts and the Land social court; and one finance court for each Land. The federation has used its powers of concurrent legislation to regulate the organization, authority, and procedures of these courts. The Land Minister of Justice and a judicial selection committee decide on the selection of judges, but the pay and benefits of the judges are set by federal law.

While the Länder have an important role in performing judicial functions, the German legal system is characterized by the dominance of federal law. Court organization, boundaries, and procedures are generally regulated by federal law. Except for the Land constitutional courts, pay and benefits are set by federal law. The interpretation of constitutional law and of ordinary federal law are basically left to the Federal Constitutional Court and the federal superior courts. All of this leads, of course, to the uniformity of judicial decision making in the German federal system.

\section{Conclusion}

The German federal system is based far more on relatively detailed written constitutional principles than is the federal system in the United States, which has evolved in reaction to political and economic developments in a long, often difficult and discontinuous historical process in which the Supreme Court has played the key role. While Federal Constitutional Court decisions have been more important in the German political system since $1949^{106}$ than court rulings in other European countries and have clarified many provisions of the Basic Law, the brevity and vagueness of the American Constitution have offered the Supreme Court even greater opportunities to shape and control the federal system in the United States.

Although the detailed written constitutional principles of the German Basic Law stand in contrast to the very general and frequently ambiguous provisions of the American Constitution, the Basic Law is still misleading 
in its provisions regarding the federal system. Article 30 suggests that the Länder are the repository of most governmental powers unless exceptions have been made by other provisions of the Basic Law. Article 70 gives the impression that the Länder have significant legislative powers, and Article 83 appears to give the Länder the right to implement federal laws on their own authority. Constitutional reality, as German legal scholars like to say, presents a quite different picture. The conditional clause, "unless the Basic Law provides otherwise," has in fact provided for federal dominance in legislation and a complex interrelationship in administration.

In terms of legislative powers, the Basic Law granted the federation a number of key exclusive powers, and from the rather long list of concurrent powers the federation has taken virtually every item for itself. Even under framework legislation, the federation has expanded its range of activities in areas normally thought to lie within the competence of the Länder. It is true that most federal laws now require the approval of the Bundesrat, but this guarantees the participation only of the Land governments (cabinets), not of the Land parliaments. It also means that Länder in the minority in Bundesrat decisions find themselves relinquishing some degree of autonomy without their consent. In spite of some minor improvements in the position of the Länder as a result of recent constitutional changes, relatively little has been left to them over the years for autonomous decision making.

While the Länder are dominant in the administrative arena, as Article 83 suggests they are, the federal government can and does become involved in administration in a number of ways. It administers on its own the laws passed under its exclusive powers, and it delegates many other laws to the Länder for administration with federal instructions. The remaining federal laws are administered by the Länder on their own responsibility, but the federal government retains some right of legal supervision. The federal government also participates with the Länder in planning and financing numerous "joint tasks."

The Länder are an important part of the judicial system, and most courts are Land courts.

But in the final analysis the federation is the dominant partner in judicial matters, especially since all courts of final appeal are federal courts and federal law regulates the organization and activities of the Land courts. As a result, there is little problem in establishing a country-wide uniformity in judicial decision making.

The result of the many centralizing tendencies in constitutional reality has led to a federal system that has been commonly described as a 
"unitary federation," while the complex administrative and financial interrelationships between federal and Land authorities and among the latter have promoted a system of "cooperative federalism." Some scholars, in turn, see cooperation as having led to Politikverflechtung or a kind of joint decision making that ends up hindering transparency and accountability. It is apparent, then, that the German federal system, like the American federal system, is a complicated array of practices and procedures and a source of continuing debate and controversy.

\section{Notes}

1 Most scholars argue that the American Constitution was created by a contract of the people rather than by a compact among the states, especially but not only because ratification took place in ratifying conventions elected by the people and not by the already existing state legislatures. See, for example, Melvin I. Urofsky, A March of Liberty: A Constitutional History of the United States (New York: Alfred A. Knopf, 1988), pp. 173, 274; Robert McClosky, The American Supreme Court (Chicago: University of Chicago Press, 1960), pp. 62-64; Daniel J. Elazar, Exploring Federalism (Tuscaloosa: University of Alabama Press, 1987), pp. 93-95; Alfred H. Kelly and Winfried A. Harbison, The American Constitution: Its Origins and Development (3rd edn; New York: Norton, 1963), p. 310.

2 In Daniel Elazar's terms, the US Constitution is the classic example of "the constitution as frame of government and protector of rights," while most Western European countries have "the constitution as code." Exploring Federalism, pp. 158-159.

3 Theodor Maunz in Theodor Maunz et al., Kommentar zum Grundgesetz (München: C. H. Beck'sche Verlagsbuchhandlung, 1989), Article 79 III, Rdnr 28-36 and Hans Ulrich Evers in Bonner Kommentar zum Grundgesetz (Heidelberg: C. F. Müller Juristischer Verlag), Article 79 Abs.3, Rdnr 212 Zweitbearbeitung.

4 Texas v. White, 7 Wall. 700 (1869).

5 Urofsky, A March of Liberty, pp. 173, 274; Kelly and Harbison, The American Constitution, pp. 306-311.

6 Elazar, Exploring Federalism, pp. 35, 199.

7 Paul E. Peterson, The Price of Federalism (Washington, DC: The Brookings Institution, 1995), p. 9.

8 Gunter Kisker, "The West German Federal Constitutional Court as Guardian of the Federal System," Publius: The Journal of Federalism 19, no. 4 (Autumn 1989), pp. 47-49.

9 Klaus Stern, Das Staatsrecht der Bundesrepublik Deutschland, vol. I (2nd edn; 
München: C. H. Beck'sche Verlagsbuchhandlung, 1984), pp. 650-651.

10 Kisker, "The West German Federal Constitutional Court," p. 49.

11 Bruno Schmidt-Bleibtreu and Franz Klein, Kommentar zum Grundgesetz (8th edn; Neuwied: Luchterhand Verlag, 1995), pp. 490-491 and 1091.

12 Stern, Das Staatsrecht, vol. I, p. 651; Konrad Reuter, Föderalismus: Grundlagen und Wirkungen in der Bundesrepublik Deutschland (5th edn; Heidelberg: Hüthig, 1996) p. 22.

13 Maunz in Maunz et al., Grundgesetz Kommentar, Article 30, Rdnr 2; Heinz Laufer, Das Föderative System der Bundesrepublik Deutschland (Bonn: Bundeszentrale für politische Bildung, 1991), pp. 86-87; Reuter, Föderalismus, p. 49.

14 The Tenth Amendment reads: "The powers not delegated to the United States by the Constitution, nor prohibited by it to the States, are reserved to the States respectively, or to the people."

15 Bodo Dennewitz in Evers, Bonner Kommentar, Article 30, Rdnr 2; Laufer, Das Föderative System, p. 86; Reuter, Föderalismus, p. 49.

16 Fritz Scharpf, "Kann es in Europa eine stabile föderale Balance geben?, in Scharpf, Optionen des Föderalismus in Deutschland und Europa (Frankfurt: Campus Verlag, 1994), p. 125.

17 There are several excellent commentaries on the Basic Law, some more detailed than others. See, for example, the detailed discussion of Articles 70-82 in Maunz and Dürig., cited above. For briefer references, see SchmidtBleibtreu and Klein, also cited above, and Grundgesetz Kommentar, edited by Michael Sachs (München: C. H. Beck’sche Verlagsbuchhandlung, 1966). More general discussions are offered in Heinz Laufer and Ursula Münch, Das föderative System der Bundesrepublik Deutschland (Bonn: Bundeszentrale für Politische Bildung, 1997); Heiderose Kilper and Roland Lhotta, Föderalismus in der Bundesrepublik Deutschland (Opladen: Leske \& Budrich, 1996), pp. 100-104; Laufer, Das Föderative System, pp. 87-94; and Reuter, Föderalismus, pp. 39-53.

18 Maunz in Maunz and Dürig, Grundgesetz Kommentar, Article 30, Rdnr 2126.

19 Ibid., Rdnr 11.

20 Ibid., Rdnr 17; Reuter, Föderalismus, pp. 51-53.

21 Ibid., Article 71, Rdnr 30-31.

22 Ibid., Article 30, Rdnr 10; for a list of such authorizations outside of Article 73, see Schmidt-Bleibtreu and Klein, Kommentar, p. 932.

23 Maunz in Maunz and Dürig, Grundgesetz Kommentar, Article 73, Rdnr 6.

24 Ibid., Rdnr 34 and 43.

25 For the text of theUnification Treaty, see Europa Archiv 45 (25 October 1990), pp. D515-536.

26 For useful articles summarizing the work of the Joint Constitutional Commission, see the entire issue of Das Parlament, vol. 44 (14 January 1994). The 
official government publication that deals in considerable detail with the Joint Constitutional Commission is the "Bericht der Gemeinsamen Verfassungskommission," Deutscher Bundestag, 12. Wahlperiode, Drucksache 12/6000, (5 November 1993).

27 An excellent discussion of the background to and results of the work of the Joint Constitutional Commission can be found in Karl Peter Sommermann, "Die Stärkung der Gesetzgebungskompetenzen der Länder durch die Grundgesetzreform von 1994," Jura, no. 8 (1995), pp. 393-399. For a brief overview in English, see Arthur B. Gunlicks, "German Federalism After Unification: The Legal/Constitutional Response," Publius: The Journal of Federalism 24 (Spring 1994), pp. 88-91.

28 Grundgesetznovelle vom 27.10. 94, BGBl I, p. 3146.

29 Schmidt-Bleibtreu and Klein, Kommentar, p. 943.

30 Daniel Halberstam and Roderick M. Hills, Jr., "State Autonomy in Germany and the United States," The Annals of the American Academy of Political and Social Science 574 (March 2001), pp. 177-178.

31 Ibid., p. 921 and 932; Maunz in Maunz and Dürig, Grundgesetz Kommentar, Article 72, Rdnr 2, 4, and 6 and Article 74, Rdnr 32. See also Sommermann, "Die Stärkung," p. 395.

32 Schmidt-Bleibtreu and Klein, Kommentar, p. 936 and Maunz in Maunz and Dürig, Grundgesetz Kommentar, Article 72, Rdnr 6.

33 Maunz in Maunz and Dürig, , Article 72, Rdnr 21-22.

34 For an excellent discussion of this issue in English, with a specific Grundgesetz Kommentar reference to land-use planning, see Clifford Larsen, "What Should be the Leading Principles of Land Use Planning? A German Perspective," Vanderbilt Journal of Transnational Law 29, no. 5 (November 1996), pp. 991-996.

35 Ursula Münch, Sozialpolitik und Föderalismus: ZurDynamik der Aufgabenverteilung im sozialen Bundesstaat (Opladen: Leske \& Budrich, 1997), pp. 143154, especially p. 152.

36 Ibid., p. 90, 143-145.

37 See Sommermann, "Die Stärkung," p. 395.

38 Maunz in Maunz and Dürig, Grundgesetz Kommentar, Article 74, Rdnr 1.

39 Schmidt-Bleibtreu and Klein, Kommentar, p. 941.

40 Paul Feuchte, "Die rechtliche Ordnung der Verwaltung im Bundesstaat und ihre Entwicklung," in Deutsche Verwaltungsgeschichte, vol. 5, edited by Kurt G.A. Jeserich, Hans Pohl und Georg-Christian von Unruh (Stuttgart: Deutsche Verlags-Anstalt, 1987), p. 131.

41 Schmid-Bleibtreu und Klein, Kommentar, p. 939.

42 Maunz in Maunz and Dürig, Grundgesetz Kommentar, Article 74, Rdnr 3.

43 Ibid., Article 75, Rdnr 32; Schmidt-Bleibtreu and Klein, Kommentar, p. 1011; also Sommermann, “Die Stärkung,” p. 397.

44 Lerche in Maunz and Dürig, Grundgesetz Kommentar, Article 83, Rdnr 8. 
45 For a discussion in English of the constitutional protection of German local governments, see Arthur B. Gunlicks, Local Government in the German Federal System (Chapel Hill: Duke University Press, 1986), pp. 103-104 and "Constitutional Law and the Protection of Subnational Governments in the United States and West Germany," Publius: The Journal of Federalism 18, no. 1 (Winter 1988), pp. 141-158.

46 Arthur B. Gunlicks, "Principles of American Federalism," in Germany and Its Basic Law: Past, Present and Future - A German-American Symposium, edited by Paul Kirchhof and Donald P. Kommers (Baden-Baden: Nomos Verlagsgesellschaft, 1993), pp. 91-108.

47 Frido Wagener always distinguished between "functional administration" (administration by tasks or functions) and "territorial administration" (Gebietsverwaltung), by which he meant unity of command, i.e., all administrative tasks carried out in one administrative territory. See, for example, his “Äußerer Aufbau von Staat und Verwaltung," in Öffentliche Verwaltung in der Bundesrepublik Deutschland, edited by Klaus König, Hans-Joachim von Oertzen, and Frido Wagener (Baden-Baden: Nomos Verlagsgesellschaft, 1981), pp. 76-80. This book was also published in English: Public Administration in the Federal Republic of Germany (Boston: Kluwer-Deventer, 1983).

48 Lerche in Maunz and Dürig, Grundgesetz Kommentar, Article 83, Rdnr 85 and 92.

49 Peterson, The Price of Federalism, pp. 55-56.

50 Rainer Wahl, "Die Organisation und Entwicklung der Verwaltung in den Ländern und in Berlin”, Deutsche Verwaltungsgeschichte, vol. 5, p. 209. See also Lerche in Maunz and Dürig, Grundgesetz Kommentar, Article 83, Rdnr 4.

51 Willi Blümel, "Verwaltungszuständigkeit," in Handbuch des Staatsrechts der Bundesrepublik Deutschland, edited by Josef Isensee and Paul Kirchhof, vol. IV, p. 904.

52 See also Stern, Das Staatsrecht, vol. II, p. 780.

53 Lerche in Maunz and Dürig, Grundgesetz Kommentar, Article 83, Rdnr 2125.

54 Dittmann in Michael Sachs (ed.), Grundgesetz Kommentar (München: C. H. Beck'sche Verlagsbuchhandlung, 1996), Article 85, Rdnr 1-5; Blümel, "Verwaltungszuständigkeit,” p. 887.

55 Stern, Das Staatsrecht, vol. II, pp. 808-809.

56 Feuchte, "Die rechtliche Ordnung," pp. 128-129.

57 BverfGE of 2 March 1999, in Deutsches Verwaltungsblatt (15 July 1999), pp. 976-978.

58 Blümel, "Verwaltungszuständigkeit," pp. 890-891.

59 Dittmann in Sachs, Grundgesetz Kommentar, Article 85, Rdnr 19.

60 Ibid., Rdnr 22, 23 and 34.

61 Daniel Thürer, Bund und Gemeinden (Berlin: Springer Verlag, 1986), p. 34. 
62 Lerche in Maunz and Dürig, Grundgesetz Kommentar, Article 83, Rdnr 21.

63 Ibid., Article 84, Rdnr 16.

64 Blümel, "Verwaltungszuständigkeit," pp. 870-871.

65 Dittmann in Sachs, Grundgesetz Kommentar, Article 84, Rdnr 28-30.

66 Feuchte, "Die rechtliche Ordnung," p. 126.

67 Kisker, "The West German Fedral Constitutional Court," pp. 50-51.

68 Blümel, "Verwaltungszuständigkeit," pp. 860, 863-864.

69 Ibid., p. 935, and Dittmann in Sachs (ed.), Grundgesetz Kommentar, Article 83, Rdnr 4.

70 Fritz W. Scharpf, Bernd Reissert and Fritz Schnabel, Politikverflechtung: Theorie und Empirie des kooperativen Föderalismus in der Bundesrepublik (Kronberg: Scriptor Verlag, 1976).

71 See Deil Wright, Understanding Intergovernmental Relations (3rd edn; Pacific Groves: Brooks/Cole, 1988).

72 Arthur Benz, "Verflechtungen der Verwaltungsebenen," in Öffentliche Verwaltung in Deutschland, edited by Klaus König and Heinrich Siedentopf (Baden-Baden: Nomos, 1996), pp. 169-172.

73 See, for example, Arthur Benz, "Intergovernmental Relations in the 1980s," Publius: The Journal of Federalism 19, no. 4 (Autumn 1989), pp. 206-209.

74 Kilper and Lhotta, Föderalismus, pp. 196-197.

75 Kommission für die Finanzreform, Gutachten über die Finanzreform in der Bundesrepublik Deutschland (Stuttgart: Verlag W. Kohlhammer, 1966); for a discussion of this report, see Kilper and Lhotta, Föderalismus, pp. 183-186; for a brief review in English, see Karl H. Cerny, "Federalism in the West German Republic," in Federalism: Infinite Variety in Theory and Practice, edited by Valerie Earle (Itasca, IL: F. E. Peacock Publishers, 1968), pp. 175-177.

76 Stern, Das Staatsrecht, vol. II, pp. 833-834; Feuchte, "Die rechtliche Ordnung," p. 140.

77 Blümel, "Verwaltungszuständigkeit," p. 945.

78 Stern, Das Staatsrecht, vol. II, pp. 834-838.

79 For a view of general decline of Land powers over the past decades, see Herbert Schnoor, "Zur Lage der Länderverwaltung nach 30 Jahren Grundgesetz," Die öffentliche Verwaltung 23, no. 10 (May 1979), pp. 355-362. For administrative cooperation in particular, see p. 357; with particular emphasis on social policy, see Münch, Sozialpolitik und Föderalismus, pp. 22-33.

80 Maunz in Maunz and Dürig, Grundgesetz Kommentar, Article 91a, Rdnr 3.

81 Kilper and Lhotta, Föderalismus, p. 198.

82 Benz, "Verflechtung der Verwaltungsebenen," p. 171.

83 Ibid., pp. 171-172.

84 Ibid., pp. 131-132; Rolf Grawert listed 224 administrative agreements in the mid-1960s covering twenty-two general topics in his book, Verwaltungsabkommen zwischen Bund und Ländern in der Bundessrepublik Deutschland (Berlin: Duncker \& Humblot, 1967), pp. 299-341. 
85 Lerche in Maunz and Dürig, Grundgesetz Kommentar, Article 83, Rdnr 92.

86 Benz, "Verflechtung der Verwaltungsebenen," p. 172.

87 Gunter Kisker, Kooperation im Bundesstaat (Tübingen: J. C. B. Mohr (Paul Siebeck), 1971), pp. 75 and 79.

88 Blümel, Verwaltungszuständigkeit,” p. 961.

89 Stern, Das Staatsrecht, vol. II, pp. 786-787.

90 Benz, "Verflechtung der Verwaltungsebenen," p. 173.

91 Stern, Das Staatsrecht, p. 787.

92 Blümel, "Verwaltungszuständigkeit," pp. 960-961.

93 Lorenz Menz, "Die Ministerpräsidentenkonferenz - ein unverzichtbares Element politischen Handelns in der Bundesrepublik Deutschland," in Der Landtag - Standort und Entwicklungen, edited by Erich Schneider (BadenBaden: Nomos Verlagsgesellschaft, 1989), pp. 86, 88-90.

94 Kisker, Kooperation, pp. 143 and 161.

95 Frido Wagener, "Gemeinsame Rahmenplanung und Investitionsfinanzierung," in Die öffentliche Verwaltung, no. 16 (August 1977), p. 588; Lerche in Maunz and Dürig, Grundgesetz Kommentar, Article 83, Rdnr 98.

96 Kisker, Kooperation, pp. 166-167, 303-304.

97 The scholar most frequently cited for this concept is Konrad Hesse, Der unitarische Bundesstaat (Karlsruhe: C. F. Müller, 192). See also Lerche in Maunz and Dürig, Grundgesetz Kommentar, Article 83, Rdnr 4.

98 Elazar, Exploring Federalism, pp. 34-38, 170-173.

99 Fritz Scharpf is most identified with this concept. See, for example, Scharpf et al., Politikverflechtung.

100 For a review of the different stages of postwar German federalism as reflected in the terms used to describe the system, see Hartmut Klatt, "Forty Years of German Federalism: Past Trends and New Developments," Publius: The Journal of Federalism 19, no. 4 (Autumn 1989), pp. 185-202.

101 Feuchte, "Die rechtliche Ordnung," p. 148.

102 Gerhard Lehmbruch, "Institutional Linkages and Policy Networks in the Federal System of West Germany," Publius: The Journal of Federalism 19, no. 4 (Autumn 1989), p. 222.

103 Fritz W. Scharpf, “Die Politikverflechtungs-Falle: Europäische Integration und deutscher Föderalismus im Vergleich," Politische Vierteljahresschrift 26, no. 4 (1985), pp. 346-350; see also an English version of this article: "The Joint-Decision Trap: Lessons from German Federalism and European Integration," Public Administration 66 (Autumn 1988), pp. 239-278.

104 This section is based on the chapter by Willi Blümel, "Rechtsprechungszuständigkeit," in Handbuch des Staatsrechts der Bundesrepublik Deutschland, vol. IV, edited by Josef Isensee and Paul Kirchhof (Heidelberg: C. F. Müller, Juristischer Verlag, 1990), pp. 966-983. See also Christoph Degenhart, "Gerichtsorganisation," in Handbuch des Staatsrechts, vol. III, pp. 859-878, and, by the same author, Staatsrecht $I$, 14th revised edn (Heidelberg: C. F. 
Müller Verlag, 1998), pp. 65-66 and 219-220; for useful general discussions, see Reuter, Föderalismus, pp. 64-67 and Laufer, Das föderative System, pp. 91-92; for a discussion of the German court system in English, see Wolfgang Heyde, Justice and the Law in the Federal Republic of Germany (Heidelberg: C. F. Müller, 1994), pp. 7-15.

105 Marbury v. Madison 1 Cranch 137; 2 L. Ed. 60 (1803).

106 Philip M. Blair, Federalism and Judicial Review in West Germany (Oxford: Clarendon Press, 1981); and by the same author, "Federalism, Legalism and Political Reality: The Record of the Federal Constitutional Court," in German Federalism Today, edited by Charlie Jeffery and Peter Savigear (New York: St. Martin's Press, 1991), pp. 63-83. 